Sains Malaysiana 49(1)(2020): 145-154

http://dx.doi.org/10.17576/jsm-2020-4901-18

\title{
Antioxidant and Anti-Diabetic Status of Popular Malay Health Tonic Consumed for Wellness: Help or Hype?
}

(Status Antioksidan dan Anti-Diabetik dalam Pengambilan Tonik Kesihatan Popular Melayu untuk Kesejahteraan: Membantu atau Mudarat?)

\author{
Mohd Nazri Zayapor, Aminah Abdullah \& Wan Aida Wan Mustapha*
}

\section{ABSTRACT}

Contemporary Malay health tonics labeled as botanical drinks are advertised in the Malaysian market as effective therapeutic supplements toward improving consumer health. The therapeutic claims associated with high antioxidants are based on the herbal ingredients used, yet unproven by scientific evidence. Moreover, they are mostly sweetened with sugar, which may arise the potential of diabetic risk. Thus, a dire clarification on the potential antioxidant status and diabetic risk of these products is essential to nullify over claims. Eight commercial botanical drinks that serve as health tonics were selected based on their advertisement popularity and traditional medicine sellers' interview feedbacks. The selected tonics were mutually compared with a green tea (DGT01) as the benchmark for their total phenolic content (TPC); antioxidant activities [the 2,2-diphenyl-1-picrylhydrazyl (DPPH) radical scavenging inhibition capacities, $I C_{50}$; Ferric ion reducing antioxidant power (FRAP); and Oxygen radical absorbance capacity (ORAC)], anti-diabetic property through the $\alpha$-glucosidase inhibition (AGI) and as well as the sugar content. The results were mapped for variations using Principal Component Analysis (PCA). Three out of 8 health tonics (NS12, SK53, and MU13) has approximately 3 to 4-fold, 1.1-fold and 2.5-fold higher in TPC, ORAC, and FRAP reducing capacities, respectively. Only NS12 and SK53 showed strong AGI (>80\% inhibition). Three tonics, NS12, SK53, and HSO6 exhibited precaution levels of sugar with more than $180 \mathrm{mg}$ of total sugars per serving. From the PCA, DGT01 was dissociated from any tonic. NS12 and SK23 were closely related in terms of antioxidant and AGI activities. Although they showed promising therapeutic benefits due to high antioxidant activities and low diabetic risk, the tonics' efficacies and safety are still dubious shall be verified by reliable clinical trials. The selection of a health tonic shall not only be based on multi antioxidant-rich ingredients but low in sugar for a healthier choice.

Keywords: Diabetes mellitus; green tea; polyphenol; spices; tonic

\section{ABSTRAK}

Tonik kesihatan Melayu kontemporari yang dilabelkan sebagai minuman botani diiklankan dalam pasaran Malaysia sebagai supplemen terapeutik yang berkesan bagi mempertingkatkan kesihatan konsumer. Akuan terapeutik ini seringkali dikaitkan dengan kandungan antioksidan yang tinggi berdasarkan ramuan rempah dan herba yang digunakan. Walau bagaimanapun, akuan tersebut jarang sekali disokong oleh bukti saintifik. Oleh itu, suatu pencerahan mengenai potensi status antioksidan dan risiko diabetik produk ini amat perlu dilakukan bagi membatalkan akuan berlebihan ini. Lapan tonik kesihatan dipilih berdasarkan populariti di media massa dan hasil daripada temu bual rawak dengan penjual ubatan tradisi. Tonik yang terpilih dibandingkan dengan teh hijau untuk kandungan fenolik keseluruhan (TPC), kekuatan penghapus radikal bebas DPPH IC ${ }_{50}$, kapasiti penurunan FRAP, kapasiti penyerapan radikal oksigen (ORAC), AGI dan juga kandungan gula. Jika dibandingkan dengan DGT01, 3 daripada 8 tonik kesihatan (NS12, SK 53 dan MU 13) masing-masing menunjukkan kira-kira 3 ke 4-kali ganda, 1.1-kali ganda dan 2.5-kali ganda lebih tinggi di dalam TPC, ORAC dan kapasiti FRAP. Hanya NS12 dan SK53 sahaja yang menunjukkan AGI yang tinggi (>80\% perencatan). Tiga tonik, NS12, SK53 dan HS06 menunjukkan paras gula yang membimbangkan dengan melebihi 180 mg jumlah gula (jumlah hasil fruktosa, glukosa dan sukrosa) setiap hidangan. Daripada PCA, DGT01 terasing daripada sebarang tonik. NS12 dan SK23 menunjukkan perkaitan hampir dalam aktiviti antioksidan dan antidiabetik. Walaupun kedua-dua tonik menunjukkan potensi manfaat terapeutik disebabkan aktiviti antioksidan dan risiko diabetik yang rendah, tetapi efikasi dan keselamatannya masih belum jelas dan perlukan kesahihan dengan percubaan klinikal. Pemilihan tonik kesihatan seharusnya tidak bersandarkan kepada beragam ramuan kaya-antioksida semata-mata tetapi rendah gula untuk pilihan yang lebih sihat.

Kata kunci: Diabetes mellitus; polifenol; rempah ratus; teh hijau; tonik 


\section{INTRODUCTION}

Health tonic is a natural medical supplement that is believed to enhance the wellbeing of the body system. It is traditionally formulated from natural herbs and/or spices to specifically strengthen the immune system by assisting the detoxification and healing process and simultaneously restore the balance of the pathological system. Its usage in the healthcare regime is casually regarded as a preventive rather than as a cure for the disease. The function of tonic similarly reflects an adaptogen in maintaining the body healthy state (Ray et al. 2016). Besides maintaining the optimal state of wellbeing, this remedy can specifically functional for the specific organ or system, which presumably acts as cardiac, hematic, digestive, nerves, or vascular. There are two types of tonics in Malaysian healthcare landscapes: herbal tonic with indication registered mainly as traditionally used for general health, which its regulatory control is under National Pharmaceutical Control Bureau, Ministry of Health Malaysia, and botanical health drink that serves as a tonic, which is regulated under Malaysian Food Act and Regulation. The drink is considered as a health tonic since its consumption volume is smaller (approximately $15 \mathrm{~mL}$ ) than the regular drink $(250 \mathrm{~mL})$ and for invigorating purposes. The therapeutic indication is largely depended on the efficacy and safety, however, the proven health evidence of the herbal drink on its efficacies that back up by reliable scientific testing is in absence. Most of these therapeutic claims are generally endorsed by traditional medicinal practitioner knowledge/ observation and mostly supported by real experience testimonies. The adverse effects by regular consumption of these tonics are in absence of reported evidence. However, the absence of evidence of these adverse effects within the context of traditional herbal medicine usage does not carry a remark of safety potential (Moreira et al. 2014). One can only approve the product safety with a comprehensive set of pre-clinical and clinical studies before indicated on the label. This in vitro analysis of antioxidant potential serves as an evaluation platform prior to the pre-clinical study.

Historically, the concept of health tonics is deeply embraced in traditional medicines by utilizing tonic herbs (Götti et al. 2014) such as Astragalus, Ginseng, and Cordyceps in Traditional Chinese Medicines (TCM); Ashwagandha and Pippali in Ayurvedic; and Dandelion root and Gentian root in Traditional European Naturopathy. Common indications for these traditional tonics are including to improve blood circulation, purifying the blood, enhancing stamina and strengthen the immunity system. In the Malay Archipelago region, Jamu is a well-known tonic but has a profound palatability drawback. In overcoming this obstacle, local manufacturers have come out with the inclusion of fruit juices and sugar in their formulation to gain higher palatability. Since the addition of sugar has been associated with the risk of diabetes, the presence of sugar in the tonic formulations can turn a risk alarm until scientific evidence was proven it is safe to be consumed by diabetic patients.
These botanical drinks that consumed as a health tonic are purportedly claimed to delay the effect of aging, alleviate the vascular problem by improving microcirculation, enhancing the lipid and carbohydrate metabolisms via modulating the activity of liver, pancreas, and spleen. However, none of these commercial health tonics had been reported to be clinically proven either in giving therapeutic or contradictory implications. All health tonics sampled are being marketed as botanical drinks instead of traditionally prepared drugs. Therefore, the preclinical or clinical efficacy test is beyond the requirement. Nowadays, with the high impact advertisements on the targeted consumers and convincing real-case testimonies, health tonic for wellness among the Malay communities is becoming sensational selling item in the Malaysia's health product landscape. In addition, herbal remedies are preferred among consumers as these are believed to be effective but has mild adverse effects and more economic viable (Ravi et al. 2017). Coupled with the high trending in the demand for natural based medicine, this botanical drink successfully drives the consumer believes that consumption of this drink can improve their health status as it claims high in antioxidants. But none of the claimed products had produced at least their antioxidant contents either via laboratory testing or having clinical trials proven. Since then, their health benefits status can be debated and may lead to false claims. Therefore, a dire demand to clarify the potential antioxidant status of those products is in need.

Tea is a worldwide consumed beverage and the green one is broadly used as a functional beverage and dietary antioxidant supplement as it contains more catechins, a potent antioxidant than the other type of Camellia sinensis tea (Tsai et al. 2013). In addition, tea has demonstrated anti-hyperglycemic properties (in animal models) but its efficacies are associated with high-dose levels (Han et al. 2016). Polyphenols are known to contribute to the dietary antioxidant upon consumption of fruits, herbs, and spices, which can be found in the tonic formulation and tea. Certain type of polyphenols can act as $\alpha$-glucosidase (an enzyme that breakdown carbohydrate into glucose in the small intestine) inhibitor (AGI), which may behave as a 'sugar blocker' in the sugary formulation. Thus, preventing the high glycemic response that relates to the diabetic symptom. The extent of sugar content influence in the formulation toward the AGI activity is unknown, thus, it needs to be determined.

Our objectives were to evaluate the in vitro antioxidant and AGI activities on the selected health tonics and concomitantly distinguish with a commercial green tea using Principal Component Analysis (PCA) based on their antioxidant level and diabetic risk (AGI activities and sugar contents).

\section{Materials AND Methods}

A total of 8 commercial health tonics of the botanical drink category was acquired from a random survey of 5 traditional health product stores at the university vicinity 
based on their mass media popularity and random interview feedback from the traditional medicine sellers. The selected tonics and green tea were coded with two to three letters followed by the number of herbal antioxidants used in the formulation as HS06, NS12, KL17, PG08, KHZ18, DGT01, MU13, SK53, and HY13. Green tea drink (DGT 01) was prepared by infusing a tea bag ( $\pm 30 \mathrm{~g}$ of dried tea leaves) in $200 \mathrm{~mL}$ hot water $\left(100^{\circ} \mathrm{C}\right)$ for $5 \mathrm{~min}$; the drink was stood to cool at room temperature and stored at $10^{\circ} \mathrm{C}$ until used. The selected tonics were mutually compared with a green tea with the following analyses.

DETERMINATION OF TOTAL PHENOLIC CONTENT (TPC), THE DPPH FREE RADICAL SCAVENGING ACTIVITY, FERRIC REDUCING ANTIOXIDANT POWER (FRAP) AND OXYGEN RADICAL ABSORBANCE CAPACITY (ORAC)

Total phenolic contents of tonics and tea drink were spectrophotometrically quantified by the Folin-Ciocalteu (FC) method (Singleton et al. 1998) with slight modification using a series of gallic acid dilutions as the standard. The tonics and the tea drink were diluted with deionized water at 1:50 ratio before a $20 \mu \mathrm{L}$ of diluted sample was mixed with $100 \mu \mathrm{L}$ of $10 \% \mathrm{FC}$ reagent in a 96-well microplate. An $80 \mu \mathrm{L}$ of $7.5 \%$ sodium carbonate was added to the mixture after 3 to $5 \mathrm{~min}$. The mixture absorbance was spectrophotometrically measured at $765 \mathrm{~nm}$ after incubation for $2 \mathrm{~h}$ at $37^{\circ} \mathrm{C}$ (Spectrostar Nano, BMG Labtech, Germany). The estimation of TPC was calculated by using the calibration curve of gallic acid and was expressed as $\mu \mathrm{g}$ of gallic acid equivalents (GAE)/mL samples.

Each tonic and tea drink were dissolved with deionized water to establish a series of 10 dilution factors. The antioxidant capacity was determined by the DPPH (2,2-diphenyl-1-picrylhydrazyl) radical-scavenging method according to Kodama et al. (2010) with some modifications. A $50 \mu \mathrm{L}$ aliquot of the diluted sample was mixed with $250 \mu \mathrm{L}$ of $0.5 \mathrm{mM}$ methanolic DPPH and after 30 min the absorbance was measured at $515 \mathrm{~nm}$ using a microplate reader (Spectrostar Nano, BMG Labtech, Germany).

The $\mathrm{IC}_{50}$ value which is the concentration of the sample required to inhibit $50 \%$ of the DPPH free radical, was calculated using a linear of curve inhibition percentage. The percent DPPH scavenging effect was calculated as DPPH inhibition capacity $(\%)=\mathrm{A}_{\text {blank }}-\mathrm{A}_{\text {sample }} / \mathrm{A}_{\text {blank }} \times 100$ where $\mathrm{A}_{\text {blank }}$ was the absorbance of control reaction; and $\mathrm{A}_{\text {sample }}$ was the absorbance in presence of the test sample. A lower $\mathrm{IC}_{50}$ value corresponds to a higher scavenging activity.

A FRAP assay of each tonic and the green tea drink were measured using a modified procedure of Musa et al. (2011). FRAP reagent was initially prepared by mixing 20 $\mathrm{mM} \mathrm{FeCl} .6 \mathrm{H}_{2} \mathrm{O}, 10 \mathrm{mM}$ TPTZ (2,4,6-tri(2-pyridyl)-striazine), and $300 \mathrm{mM}$ acetate buffer, $\mathrm{pH} 3.6$ at the ratio of 1: 1: 10 , respectively. A $1950 \mu \mathrm{L}$ of FRAP reagent was mixed with $50 \mu \mathrm{L}$ test sample and left incubated for $30 \mathrm{~min}$ at room temperature. The mixture absorbance was measured at $595 \mathrm{~nm}$. The reducing antioxidant capacities were estimated by applying the Trolox calibration curve and the results were expressed as $\mathrm{mM}$ Trolox equivalents (TE)/mL of samples.

A minor adjustment of the ORAC method as described by Cao et al. (1993) was used where a $25 \mu \mathrm{L}$ diluted sample was mixed with $150 \mu \mathrm{L}$ of $10 \mathrm{~nm}$ Fluorescein solution in a 96-well black plate. Then, the fluorescence measurements (520 $\mathrm{nm}$ emission, and $485 \mathrm{~nm}$ excitation) were taken every 90 min using a microplate reader (FLUORstar Omega, BMG Labtech, Germany) after the mixtures were incubated for $30 \mathrm{~min}$ at $37^{\circ} \mathrm{C}$. At the fourth cycle, $25 \mu \mathrm{L}$ of $240 \mathrm{mM}$ AAPH was automatically injected and the measurement was resumed. The results were expressed as $\mu \mathrm{M}$ Trolox equivalents (TE)/mL of liquid samples.

\section{DETERMINATION OF $\alpha$-GLUCOSIDASE INHIBITION CAPACITIES}

The $\alpha$-glucosidase inhibition assay was adapted from Gulati et al. (2012). A $50 \mu \mathrm{L}$ of blank (buffer solution)/sample/ standard was mixed with $50 \mu \mathrm{L}$ of yeast $\alpha$-glucosidase $(0.5$ $\mathrm{U} / \mathrm{mL}$ in $0.1 \mathrm{M}$ potassium phosphate buffer solution, $\mathrm{pH6.9)}$ in a 96 -well plate. After $15 \mathrm{~min}$ of pre-incubation at $37^{\circ} \mathrm{C}$, $125 \mu \mathrm{L}$ of $10 \mathrm{mM} \rho$-Nitrophenyl- $\alpha$-glucopyranoside ( $\rho$-NPG) in $0.1 \mathrm{M}$ phosphate buffer was added to each well and further re-incubated for $30 \mathrm{~min}$. The reaction mixture was later added with $125 \mu \mathrm{L}$ of $0.1 \mathrm{M}$ sodium carbonate solution and re-incubated for $20 \mathrm{~min}$ at $37^{\circ} \mathrm{C}$. The absorbance was measured at $405 \mathrm{~nm}$. The $\alpha$-glucosidase activity was determined by linear regression of quercetin standard curves and the results were expressed as Quercetin equivalent, QE $\mu \mathrm{g} / \mathrm{mL}$. The percentage of enzyme inhibition by the sample was calculated by the following formula:

$\begin{aligned} \% \text { Inhibition capacity }= & \left(\text { Absorbance }_{\text {blank }}-\text { Absorbance }_{\text {sample }}\right) / \\ & \left(\text { Absorbance }_{\text {blank }}\right) \times 100\end{aligned}$

HPLC DETERMINATION OF SUGAR CONTENTS

Three standard sugars (fructose, glucose and sucrose) were dissolved in acetonitrile/water (70:30) mixture to make a stock solution of $1000 \mathrm{ppm}$. A serial dilution of four further concentrations of the standards were prepared to compose a five-point calibration curve using the standard values. Each tonic was directly mixed with deionized water in a ratio of 1:4. The mixtures were vortex for $5 \mathrm{~min}$ before centrifuged at $10000 \mathrm{rpm}$ for $10 \mathrm{~min}$ at room temperature. The supernatants were then filtered using a Whatman nylon $0.45 \mu \mathrm{m}, 25 \mathrm{~mm}$ diameter syringe filter. The filtrate was further diluted 20-fold with acetonitrile/water mixture before a $10 \mu \mathrm{L}$ volume of diluted sample was injected on to a Luna Omega $3 \mu \mathrm{m}$ SUGAR at $35^{\circ} \mathrm{C}$ (Odumosu \& Dayol 2015). The chromatographic analyses were carried out using a HPLC (Waters Corp., USA) and ELSD (PL-ELS 1000 ), operating at $60^{\circ} \mathrm{C}$ and nitrogen pressure of $230 \mathrm{kPa}$. 
The analysis was carried out by isocratic elution at a flow rate of $1 . \mathrm{mL} / \mathrm{min}$ using the mixture of acetonitrile/water (70: 30) (Montesano et al. 2016).

The total soluble solids were measured using a handheld refractometer and recorded as in ${ }^{\circ}$ Brix. The lightness of each sample was measured using a color meter (CR-200, Minolta, Osaka, Japan) and recorded as $\mathrm{L}^{*}$ values $(0=$ black/dark, $100=$ white/light). Data for carbohydrate $(\mathrm{g} / 100 \mathrm{~mL})$ and energy $(\mathrm{kCal})$ were obtained from the respective sample nutritional labeling.

\section{StATISTICAL ANALYSIS}

All test analyses were conducted in triplicate. For discriminating the high antioxidant tonics and an insight into relationships between the variables, data were subjected to multivariate principal component analysis (PCA) using XLSTAT Premium Annual Version 2018.5.52211 (Addinsoft Inc., New York, NY, USA). Results are presented as the mean \pm standard deviation where $\mathrm{p}<0.05$ was considered statistically significant. All data were analyzed statistically using SPSS (Statistical Package for Social Science) ver. 20 (IBM, California, USA). While, Pearson's correlation coefficient was done to obtain the correlation of TPC, DPPH IC ${ }_{50}$, FRAP, ORAC, \%AGI, AGI $\mathrm{QE}$, sugar assay values, as well as energy count, and carbohydrate values from labelling using the initial software.

\section{RESUlts AND Discussion}

\section{TOTAL PHENOLIC CONTENTS (TPC), DPPH FREE RADICAL SCAVENGING CAPACITIES, FERRIC-ION REDUCTION CAPACITIES AND ORAC VALUES}

Phenolic compounds are essentially contributing to the dietary antioxidant. The consumption of phenolic-rich diets has been positively associated with low risk of metabolic syndrome (Shahidi \& Ambigaipalan 2015). This dietary antioxidant is served as the indicator of antioxidant activities since it mainly consists of free radical scavenger (FRS) due to their hydroxyl groups that potently inhibit oxidation activities. The non-oxidized polyphenols of green tea (Camellia sinensis) have been demonstrated in vitro as the potent antioxidants by scavenging reactive oxygen species (ROS) or chelating transition metals (Forester \& Lambert 2011). It has a higher antioxidant capacity than regularly consumed black tea and coffee (Anissi et al. 2014). This nominates the green tea as an ideal benchmark among the regular beverage for consumed dietary antioxidant intake (Taguchi et al. 2015). From Table 1(a), the top 3 tonics, MU12, SK53, and NS13 contained almost significantly 3 to 4 -fold higher $(\mathrm{p}<0.05)$ in TPC than the benchmark green tea, DGT01. Only 4 out of 8 tonics (PG08, HS06, HY23, and KZ18) showed significantly lower TPC than the DGT01, which the latter tonic is the least. The lower TPCs in those tonics was thought to be attributed to the lower quantities of the antioxidant-rich ingredient (AORI). Even though the number of AORI is more than 10, it does not reflect that the more AORI necessarily contained the more TPC. This suggests that the concentration or quantity or even type of the added AORI may contribute a higher influence on the TPC. Most of the tonic producers are keen to claim that their products are therapeutically better due to the number of AORI added. These exaggerated claims shall be nullified until further supported by scientific evidence to eradicate the health hype and risk. Nevertheless, we are urged to consumed multi-source of dietary antioxidants since not a single antioxidant can neutralize every free radical and oxidative substances. Herbal antioxidants that rich in a different type of antioxidants may complement the dietary needs.

Free radical scavenging activity potency is usually measured by the concept of $\mathrm{IC}_{50}$, where, the concentration of an inhibitor is reduced by half. The smaller the $\mathrm{IC}_{50}$ value the more potent the inhibitory capacities. All 8 tonics showed lower potencies in scavenging the free radical compared to DGT01. NU12 is comparatively a strong potent free radical scavenger as the green tea but lower to more than 1.5-fold (Table 1(a)) and followed closely by SK53 (lower to more than 2.3-fold). The rest of the tested tonics were obviously less potent $(>200 \mu \mathrm{L} / \mathrm{mL})$, where the HY23 and PG08 were the least (21.5-fold and 26.3-fold lower, respectively). The latter tonic major ingredient was pomegranate extract which was reported to be the most potent among fruit juice tested with an $\mathrm{IC}_{50}$ value of 5.5\% (v/v) (Marjanović et al. 2015). The expressed unit used in most DPPH IC I0 $_{5}$ assay in weight/volume. In this case study, it is more appropriate to expressed in volume/volume unit since it consumes by volume instead of weight. The green tea extract was reported to be most active DPPH scavenging activity compared to the standard of pure compounds: catechin, quercetin, kaempferol, and myricetin showed by the low $\mathrm{IC}_{50}$ value of $0.487 \mu \mathrm{g} / \mathrm{mL}$ (Widowati et al. 2015). It still shows that green tea has a strong potency towards reducing oxidative stress due to the free radicals when compared to the tonics. Therefore, it is still worthy to consider the economic-feasible green tea as the best source of dietary free radical scavenger to combat off oxidative stress.

It was observed that MU13, SK53, and NU12 were high in ferric reducing capacities (FRC) at $30 \mathrm{~min}$ incubation period which each is almost 2.5-fold higher than DGT01 (Table 1(a)). Both HY23 and PG08 have the least FRC with almost 6-fold lower than the benchmark. The number of AORI repeatedly failed to show its great influence on the health tonic antioxidant activities. The three tonics, MU13, SK53, and NU12 were not only possessed primary antioxidant activities (free radical scavenger/hydrogen atom donor) but secondary antioxidant (ferric ion reducing agent) as well. The latter type of antioxidant play a preventive role in preventing further oxidation through metal chelation (inactivate metal ion that catalyzes oxidation), inhibit/decompose 
hydroperoxidases or scavenging the oxygen (Kasote et al. 2015). If a tonic having these both type of antioxidants, we can postulate as the strong therapeutic agents due to multi-mechanism oxidation combat.

NU12, MU13, and SK53 repetitively showed high antioxidant activities. The three tonics were significantly 1.1-fold higher in ORAC value than DGT01 (Table 1(a)), which is related to their high TPC. However, this trend was contradicted to KL17 and DGT01which not only low in TPC but FRAP value as well. The trend dissimilarity was probably due to a different phenolic profile that contribute to related antioxidant mechanism. PG08 and HY23 exhibited repetitive trend as low in antioxidant (ORAC activities were below than $3000 \mu \mathrm{M}$ TE/mL). The peroxyl radical-quenching effects are measured by the loss of fluorescence quenched by the antioxidant over time (Apak et al. 2013). Peroxyl radicals are predominantly formed in lipid oxidation in biological systems. This indicated that the 3 tonics are having a high potential against lipid peroxidation.
ALPHA-GLUCOSIDASE INHIBITION CAPACITY, SUGAR CONTENTS, CARBOHYDRATE AND ENERGY LABELING

Regulated glucose metabolism is the key to control diabetes. The hallmark of diabetes management is to control the postprandial blood glucose, which can be achieved using $\alpha$-glucosidase (AG) inhibitor. Dietary polyphenols can serve in regulating the glucose homeostasis at multiple stages, particularly at the primary stage of decreasing the glucose bioavailability (Kim et al. 2016). Only half of the total health tonics tested showed positive inhibition against $\alpha$-glucosidase, SK53, NU12, MU13, and PG08 (Table 1(b)). The latter sample was the least with less than 30\% inhibition capacity and MU13 was almost close to DGT01 yet less than 50\% inhibition. However, the AG quercetin-equivalent (QE) value of MU13 was almost 5-fold lower than the AG QE value of the benchmark. This postulate that the inhibitory activity might not derive from the flavonoid but complex non-starch polysaccharides from food hydrocolloid (Zaharudin et al. 2019). The two initial

TABLE 1(a). Total phenolic content and antioxidant activities of selected contemporary health tonics

\begin{tabular}{|c|c|c|c|c|}
\hline Tonics & $\begin{array}{l}\text { Total phenolic content } \\
\quad(\mathrm{GAE} \mu \mathrm{g} / \mathrm{mL})\end{array}$ & $\begin{array}{l}\text { IC50, } \mu \mathrm{L} / \mathrm{mL} \text { inhibition } \\
\text { capacities }\end{array}$ & $\begin{array}{l}\text { FRAP reducing capacity } \\
(\mathrm{mM} \mathrm{TE} / \mathrm{mL})\end{array}$ & $\begin{array}{c}\text { Oxygen radical absorbance capacity } \\
\text { (ORAC) }(\mu \mathrm{M} \mathrm{TE} / \mathrm{mL})\end{array}$ \\
\hline HS06 & $220.61 \pm 13.20$ & $484.92 \pm 26.18$ & $3.14 \pm 0.06$ & $4154.89 \pm 73.06$ \\
\hline KL17 & $538.63 \pm 28.14$ & $269.43 \pm 69.02^{\mathrm{a}}$ & $7.30 \pm 1.35^{\mathrm{a}}$ & $6926.79 \pm 64.67$ \\
\hline PG08 & $394.72 \pm 42.98$ & $801.74 \pm 17.96$ & $2.31 \pm 0.82 b$ & $1579.81 \pm 68.41$ \\
\hline KHZ18 & $143.86 \pm 1.29^{\mathrm{a}}$ & $252.11 \pm 9.46^{\mathrm{a}}$ & $6.93 \pm 1.11^{\mathrm{a}}$ & $5271.66 \pm 65.94$ \\
\hline DGT01 & $483.32 \pm 45.64$ & $30.61 \pm 2.76$ & $11.23 \pm 0.25$ & $6288.30 \pm 25.83$ \\
\hline NS12 & $1492.57 \pm 19.19$ & $46.86 \pm 0.76$ & $28.33 \pm 0.66^{\mathrm{c}}$ & $7375.07 \pm 37.88$ \\
\hline MU13 & $1939.32 \pm 10.60^{\mathrm{b}}$ & $210.04 \pm 19.30$ & $29.93 \pm 0.24^{\mathrm{c}}$ & $7004.33 \pm 55.50^{\mathrm{a}}$ \\
\hline SK53 & $1695.30 \pm 37.62^{b}$ & $71.37 \pm 1.36$ & $28.41 \pm 0.48^{\mathrm{c}}$ & $6985.70 \pm 83.26^{\mathrm{a}}$ \\
\hline HY23 & $166.88 \pm 31.51^{\mathrm{a}}$ & $657.29 \pm 27.88$ & $1.91 \pm 0.02^{\mathrm{b}}$ & $2538.63 \pm 35.39$ \\
\hline
\end{tabular}

Mean values in a column superscripted by the same letter are not significantly different at $\mathrm{p}<0.05$

TABLE 1(b). Antidiabetic activities and glycemic parameters of selected health tonics

\begin{tabular}{|c|c|c|c|c|c|c|c|c|}
\hline Tonics & $\begin{array}{c}\% \\
\text { glucosidase } \\
\text { inhibition }\end{array}$ & $\begin{array}{c}\alpha \text {-glucosidase } \\
\text { inhibition }(\mathrm{QE} \\
\mu \mathrm{g} / \mathrm{mL})\end{array}$ & $\begin{array}{c}\text { Total } \\
\text { Soluble } \\
\text { Solid } \\
\text { ('Brix) }\end{array}$ & $\begin{array}{c}\text { Fructose } \\
(\mathrm{mg} / \mathrm{mL}) / \\
\text { per serving } \\
(\mathrm{mg})\end{array}$ & $\begin{array}{c}\text { Sugars } \\
\text { Glucose } \\
(\mathrm{mg} / \mathrm{mL}) \\
\text { per serving } \\
(\mathrm{mg})\end{array}$ & $\begin{array}{c}\text { Sucrose } \\
(\mathrm{mg} / \mathrm{mL}) \\
\text { per serving } \\
(\mathrm{mg})\end{array}$ & $\begin{array}{c}\text { Carbohydrate } \\
\text { (g per } 100 \\
\mathrm{~mL})\end{array}$ & $\begin{array}{c}\text { Energy (per } \\
100 \mathrm{~mL}), \\
\text { Kcal }\end{array}$ \\
\hline HS 06 & 0.00 & 0.00 & 20.49 & $5.85 / 87.77$ & $5.76 / 86.47$ & $0.99 / 14.87$ & 22.30 & 103.00 \\
\hline KL 17 & 0.00 & 0.00 & 27.50 & $4.30 / 64.47$ & $2.82 / 42.29$ & $2.30 / 34.53$ & 25.20 & 105.10 \\
\hline PG 08 & $26.12 \pm 1.15$ & $1827.30 \pm 62.45$ & 5.02 & $0.76 / 22.65$ & $0.63 / 19.02$ & 0.00 & 5.30 & 21.00 \\
\hline KHZ 18 & 0.00 & 0.00 & 12.02 & $2.40 / 35.98$ & 1.93 / 28.99 & 0.00 & 9.50 & 39.00 \\
\hline DGT 01 & $47.31 \pm 0.67$ & $9722.80 \pm 256.97$ & 0.10 & 0.00 & 0.00 & 0.00 & 0.00 & 0.00 \\
\hline NS 12 & $85.7 \pm 0.5$ & $12699.25 \pm 69.05$ & 19.5 & $4.50 / 89.95$ & 4.63 / 92.67 & 0.00 & 15.90 & 62.00 \\
\hline MU 13 & $49.22 \pm 1.81$ & $2090.87 \pm 139.24$ & 17.02 & $4.38 / 65.64$ & 4.63 / 69.42 & 0.00 & 30.00 & 123.33 \\
\hline SK 53 & $91.49 \pm 0.30$ & $13488.11 \pm 41.79$ & 20.83 & 6.04 / 90.54 & $6.23 / 93.52$ & 0.00 & 23.10 & 93.00 \\
\hline HY 23 & 0.00 & 0.00 & 9.01 & $1.39 / 20.90$ & $3.91 / 58.67$ & 0.00 & 45.33 & 193.33 \\
\hline
\end{tabular}


samples displayed their AG inhibition for more than $80 \%$ inhibition. This in parallel with their $\mathrm{QE}$ values with almost $13,000 \mu \mathrm{g} / \mathrm{mL}$, which is 1.3 to 1.4 -fold higher than the DGT01. The AGI capacities in these 4 tonic samples most probably contributed by the pomegranate as the main ingredients. Pomegranate ellagitannins were believed to largely inhibit the glucosidase activities in an in vitro digestive model (Bellesia et al. 2015). While in SK53, the high inhibition activity might be synergistically influenced by 4 types of berry fruits used. Berry polyphenols were found to be effective in inhibiting the AGI and showed synergy with acarbose in controlling glycemic response (Boath et al. 2012). Even though SK53 and NU12 showed the most promising antidiabetic activity, their sugary and high caloric contents give a cautious health concern.

KL17 exhibited the highest total soluble solid content (TSSC) (27.5 ${ }^{\circ}$ Brix) that contradicted with HY23 and PG08, which portrayed the least of less than $10^{\circ}$ Brix TSSC (Table 1(b)). On average, most tonics display approximately 18 ${ }^{\circ}$ Brix TSS which can be described as thin syrupy consistency. Soluble solids in food products are dissolved matters that include sugars, vitamins, minerals, and phenolic compounds. In the beverage industry, the Brix degree is used to measure the percentage of sucrose by weight in pure water solution. In this case, KL17 has 30 ${ }^{\circ}$ Brix TSS which can be translated as $30 \mathrm{~g}$ of sucrose in $100 \mathrm{~g}$ of liquid. However, the reading does not reflect the real sucrose content as the tonic might not have sucrose as the major constituent but high in bulking agent such as food gum in this case. The high reading value of ${ }^{\circ}$ Brix may also be contributed by high phenolic compound and natural pigment as these phytochemical can retract light and contribute up to $32 \%$ deviation (Magwaza \& Opara 2015). Therefore, the TSSC reading only appropriate for the indication of merely dissolve matter in the tonic but not as the prediction of total sugar content in tonics.

Dietary sugars mainly derived from fructose, glucose, and sucrose, especially in beverages. PG08 surprisingly has the lowest fructose content of $<1 \mathrm{mg}$ per $\mathrm{mL}$. Other low fructose $(<5 \mathrm{mg}$ per $\mathrm{mL})$ tonics include HY23, KHZ18, KL17, MU13, and NS12 in descending manner. Both SK53 and HS06 contained high fructose $(>5 \mathrm{mg} / \mathrm{mL})$, but when compared in per serving unit, NS12 has almost the amount of fructose consumed (approximately $90 \mathrm{mg}$ per serving) as the two high-fructose tonics. A similar fashion in the content of glucose followed for all sampled tonics. None of the tonics contained sucrose except HS06 and KL17, where the latter contained $34.5 \mathrm{mg}$ per serving. Three tonics, NS12, SK53, and HS06 can be considered high in sugar as they contained more than $180 \mathrm{mg}$ of total sugars (total sum of three sugars) per serving. However, HY23 has the highest carbohydrate content of more than $45 \mathrm{~g} / 100$ $\mathrm{mL}$ or about $1.2 \%$ was contributed by the total sugars. While total sugars in NS12 contributed to $57.4 \%$ of the carbohydrate content. This suggested that polysaccharide food gums added to the tonics are the major contributor to the high carbohydrate content beside sugars. The high carbohydrate content of HY23 was reflected in the high energy value (approximately $190 \mathrm{kCal}$ ). This was contradicted to PG08 and KHZ18 which were having 80\% - 90\% lower in energy count, respectively. In a recent survey, Malaysians consumed sugar as high as $21 \mathrm{~g}$ daily, which still observed as below the WHO recommendation of $50 \mathrm{~g}$ of sugar per $2000 \mathrm{kCal}$ daily (Amarra et al. 2016). However, this can lead to ambiguous report since consumers became sedentary as they age and require less caloric intake. Therefore, the dietary intervention of lowsugar low-calorie intake (either diet or supplement) is favored to successfully modulate the low inflammation cluster like hyperglycemia (Ostan et al. 2016). When combining calorie restriction strategy with complex carbohydrate intake, one can improve the eating quality particularly the elderly. From the aspect of eating quality, it is sensible to follow the dietary guidance but the presence of AGI phytochemicals that may act as sugar-blockers (responsible phytochemical and their inhibition mechanism) to the sugary ingredients in the tonics is a potential finding yet to be explored.

\section{CLASSIFICATION OF HEALTH TONICS USING PCA}

The biplot (Figure 1) explained about $73 \%$ variance where the first loading (F1) made up almost $50 \%$ of the variance. All antioxidant and antidiabetic variables were positively loaded except for the negatively loaded DPPH $\mathrm{IC}_{50}$ i.e. the lower the $\mathrm{IC}_{50}$ value the higher antioxidant potency. The bench marker, DGT01 was highly dissociated with any tonic sample and variable/parameter. This showed that DGT01 has a fair quality in the studied parameters yet a decent bench marker. NS12 and SK53 can be associated as a group that high in antioxidant and antidiabetic activities but relatively has a considerable amount of sugars. The opposing group were affiliated to PG08 and KHZ18. The number of AORI do not show any specific trend, even tough, some of the tonic used a handful of known potent AORI as the ingredient.

Referring to Table 2, it shows that TPC is strongly positive-correlated to the FRAP value and percentage of AGI but moderately positive-correlated to ORAC and AGI QE values $\left(r^{2}=0.968,0.828,0.664\right.$, and 0.603 , respectively) (Table 2). Meanwhile, the $\mathrm{IC}_{50}$ value is strongly and moderately negative-correlated with the ORAC and FRAP values $\left(r^{2}=-0.942\right.$ and $r^{2}=-0.722$, respectively). It showed that most of the phenolic presented has the strong hydroxyl and peroxyl scavenging capabilities but moderate in ferric reduction and AGI capabilities. Additionally, a high hydrophilic antioxidant content exhibited a stronger scavenging potency of the tonics. The total sugar content here does not influence any antioxidative property of the tonics. Thus, explained that the antioxidant activities do not derived from the total sugar.

The intense colored tonics (PG08 and HY23) regardless of color (range from yellowish brown to purplish red) are typically stereotyped as high in antioxidants. However, color intensities could be the prejudice indicator for tonic selection and could not be the predicative tool for selecting 


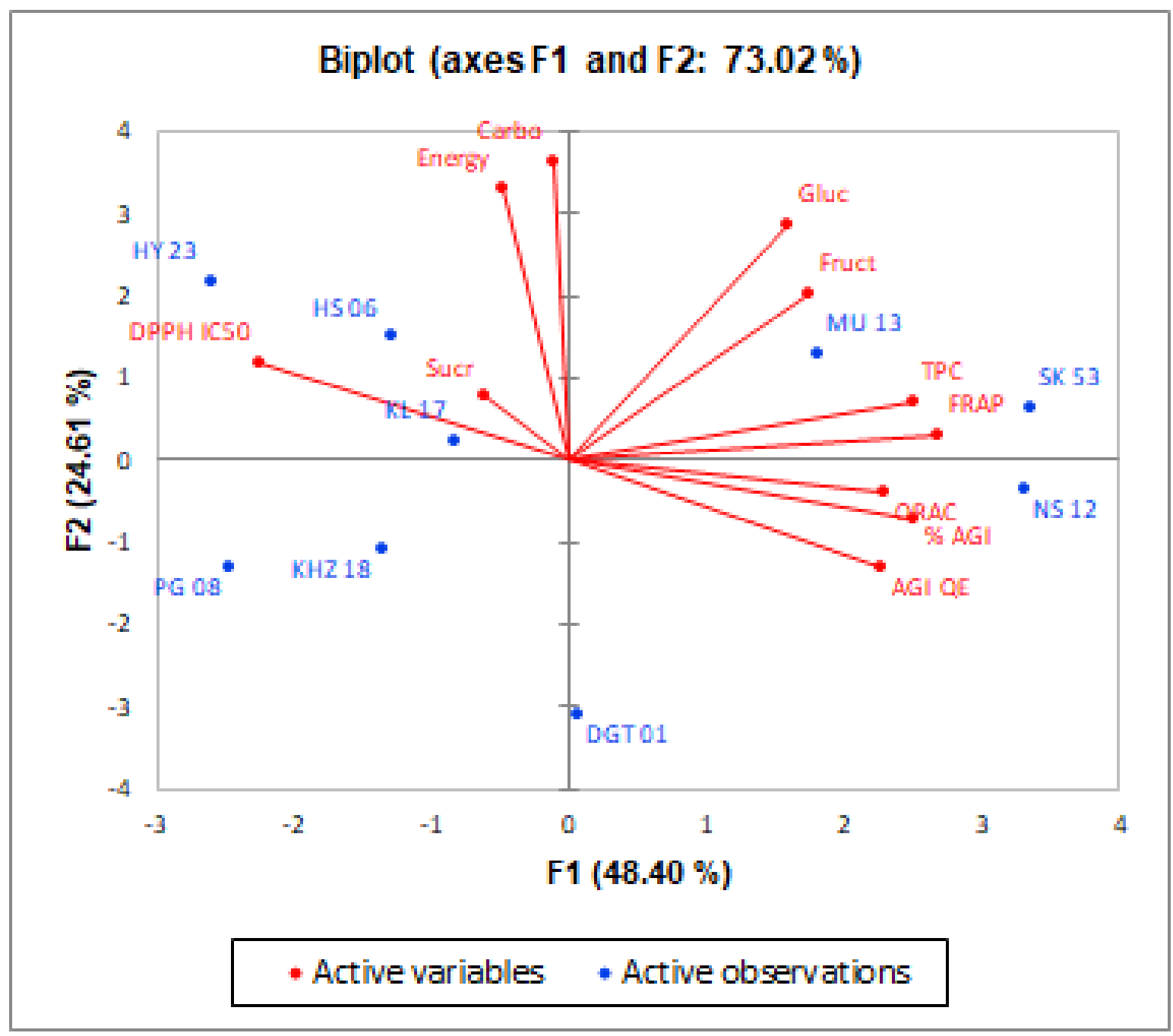

FIGURE 1. The Biplot of Health tonics and their parameters of antioxidant, antidiabetic and sugar contents

tonic with high antioxidant. Unlike honey, where color intensities significantly correlate with antioxidant capacity (Pontis et al. 2014). Therefore, the tonic color intensities (the $\mathrm{L}$ values) have been opted out since they may show ambiguity on the level of antioxidant perception.

\section{CONCLUSION}

The use of green tea as the benchmark has a few limitations on the study. Green tea drink is a monoherbal liquid, whereas the sampled tonics are polyherbal in nature. Thus, the latter has a broader variation in polyphenol contents and the antioxidant activities, which depend on the ingredient used. Moreover, the green tea chosen does not entirely represent the 'standard' green tea. However, a comparison of the selected tonics with a daily beverage like green tea rather than a conventional antidiabetic drug of the similar mechanism of action in alleviating the diabetic symptom was preferred since the health tonic is consumed as a functional drink instead as a medicated tonic.
Consumption of a myriad source of dietary antioxidant is favored as each of them possesses unique antioxidant activity. Health tonic may contribute as a source of dietary antioxidant in the community preventive health care, but few considerations must be placed in attention, especially when the product bear the health claim and added sugar. Consumers shall be provided with some cue on antioxidant status not solely based on multi antioxidant-rich ingredients and low in sugar for a healthier choice but on credible lab testing as well. Even though some tonics showed promising therapeutic values through their high antioxidant and antidiabetic activities, the efficacies and safety of those tonics shall be verified by reliable clinical trials. These findings highlight the potential for a reformulation of lower-calorie health tonics by means of sugar and polysaccharide food gum reduction.

\section{ACKNOWLEDGEMENTS}

The authors would like to express their gratitude for the research grant from Natural Medicine Research Center, Universiti Islam Malaysia, Cyberjaya and Antioxidant Lab, 


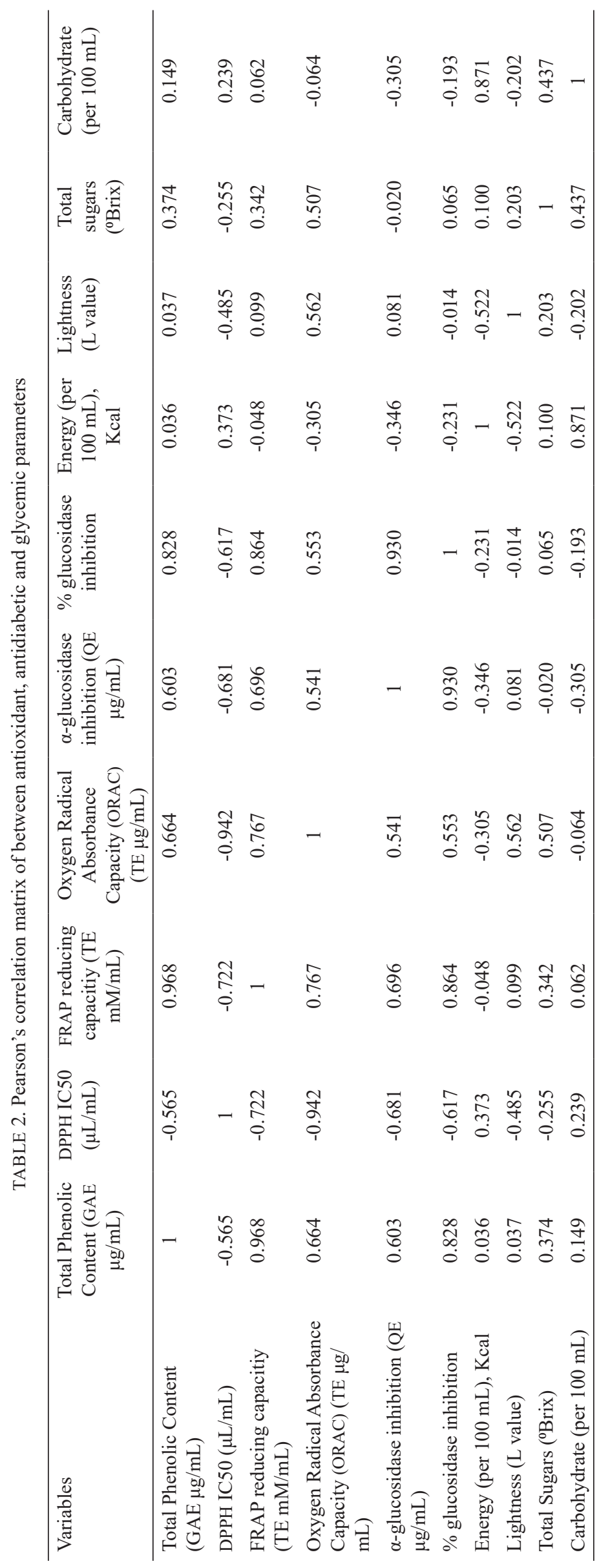


Faculty of Science and Technology, Universiti Kebangsaan Malaysia for providing the facilities for the antioxidant analysis.

\section{REFERENCES}

Amarra, M.S.V., Khor, G.L. \& Chan, P. 2016. Intake of added sugar in Malaysia: A review. Asia Pacific Journal of Clinical Nutrition 25(2): 227-240. doi:10.6133/ apjen.2016.25.2.13.

Anissi, J., El Hassouni, M., Ouardaoui, A. \& Sendide, K. 2014. A comparative study of the antioxidant scavenging activity of green tea, black tea and coffee extracts: A kinetic approach. Food Chemistry 150: 438-447. doi:10.1016/j. foodchem.2013.11.009.

Apak, R., Gorinstein, S., Böhm, V., Schaich, K.M., Özyürek, M. \& Güçlü, K. 2013. Methods of measurement and evaluation of natural antioxidant capacity/activity (IUPAC Technical Report). Pure Appl. Chem. 85(5): 957-998. doi:10.1351/ PAC-REP-12-07-15

Bellesia, A., Verzelloni, E. \& Tagliazucchi, D. 2015. Pomegranate ellagitannins inhibit $\alpha$-glucosidase activity in vitro and reduce starch digestibility under simulated gastro-intestinal conditions. International Journal of Food Sciences and Nutrition 66(1): 85-92. doi:10.3109/0963748 6.2014 .953455 .

Boath, A.S., Stewart, D. \& McDougall, G.J. 2012. Berry components inhibit $\alpha$-glucosidase in vitro: Synergies between acarbose and polyphenols from black currant and rowanberry. Food Chemistry 135(3): 929-936. doi:10.1016/j.foodchem.2012.06.065.

Cao, G., Alessio, H.M. \& Cutler, R.G. 1993. Oxygen-radical absorbance capacity assay for antioxidants. Free Radical Biology and Medicine 14(3): 303-311. doi:10.1016/08915849(93)90027-R

Forester, S.C. \& Lambert, J.D. 2011. The role of antioxidant versus pro-oxidant effects of green tea polyphenols in cancer prevention. Molecular Nutrition \& Food Research 55(6): 844-854. doi:10.1002/mnfr.201000641.

Götti, R.P., Melzer, J. \& Saller, R. 2014. An approach to the concept of tonic: Suggested definitions and historical aspects. Forschende Komplementärmedizin/Research in Complementary Medicine 21(6): 413-417.

Gulati, V., Harding, I.H. \& Palombo, E.A. 2012. Enzyme inhibitory and antioxidant activities of traditional medicinal plants: Potential application in the management of hyperglycemia. BMC Complementary and Alternative Medicine 12: 77. doi:10.1186/1472-6882-12-77.

Han, M., Zhao, G., Wang, Y., Wang, D., Sun, F., Ning, J., Wan, X. \& Zhang, J. 2016. Safety and anti-hyperglycemic efficacy of various tea types in mice. Scientific Reports 6(4): 31703. doi:10.1038/srep31703.

Kasote, D.M., Katyare, S.S., Hegde, M.V. \& Bae, H. 2015. Significance of antioxidant potential of plants and its relevance to therapeutic applications. International Journal of Biological Sciences 11(8): 982-991. doi:10.7150/ ijbs. 12096.

Kim, Y.A., Keogh, J.B. \& Clifton, P.M. 2016. Polyphenols and glycemic control. Nutrients 8(1): 1-27. doi:10.3390/ nu8010017.

Kodama, D., Gonçalves, A., Lajolo, F. \& Genovese, M. 2010. Flavonoids, total phenolics and antioxidant capacity:
Comparison between commercial green tea preparations. Ciência e Tecnologia de Alimentos 30(4): 1077-1082. doi:10.1590/S0101-20612010000400037.

Magwaza, L.S. \& Opara, U.L. 2015. Analytical methods for determination of sugars and sweetness of horticultural products-A review. Scientia Horticulturae 184: 179-192. doi:10.1016/j.scienta.2015.01.001

Marjanović, A., Đeđibegović, J., Brčaninović, M., Omeragić, E., Čaklovica, F., Dobrača, A. \& Šober, M. 2015. Antioxidant potential of selected traditional plant-based beverages in Bosnia and Herzegovina. Bulletin of the Chemists and Technologists of Bosnia and Herzegovina 45(2015): 20132016.

Montesano, D., Cossignani, L., Giua, L., Urbani, E., Simonetti, M.S. \& Blasi, F. 2016. A simple HPLC-ELSD method for sugar analysis in goji berry. Journal of Chemistry 2016: 6271808. doi:10.1155/2016/6271808.

Moreira, D.d.L., Teixeira, S.S., Monteiro, M.H.D., De-Oliveira, A.C.A.X. \& Paumgartten, F.J.R. 2014. Traditional use and safety of herbal medicines. Brazilian Journal of Pharmacognosy 24(2): 248-257. doi:10.1016/j. bjp.2014.03.006.

Musa, K.H., Abdullah, A., Jusoh, K. \& Subramaniam, V. 2011. Antioxidant activity of pink-flesh guava (Psidium guajava L.): Effect of extraction techniques and solvents. Food Analytical Methods 4(1): 100-107. doi:10.1007/s12161010-9139-3

Odumosu, P.O. \& Dayol, A.D. 2015. Determination of the sugar content in fruit flavoured drinks by HPLC. Journal of Pharmacy and Bioresources 12(2): 144-149. doi:10.4314/ jpb.v12i2.9.

Ostan, R., Bene, M.C., Spazzafumo, L., Pinto, A., Donini, L.M., Pryen, F., Charrouf, Z., Valentini, L., Lochs, H., BourdelMarchasson, I., Blanc-Bisson, C., Buccolini, F., Brigidi, P., Franceschi, C. \& d'Alessio, P.A. 2016. Impact of diet and nutraceutical supplementation on inflammation in elderly people. Results from the RISTOMED study, an open-label randomized control trial. Clinical Nutrition 35(4): 812818. doi:10.1016/j.clnu.2015.06.010

Pontis, J.A., Antonio, L., Alves, M., José, S. \& Flach, A. 2014. Color, phenolic and flavonoid content, and antioxidant activity of honey from Roraima, Brazil. Food Science and Technology 34(1): 69-73.

Ravi, K., Jose, R., Sumitha, S.K., Johny, T., Krishnaveni, K., Shanmuga Sundaram, R. \& Sambath Kumar, R. 2017. An overview of treatment challenges and the role of herbal antioxidants in diabetes mellitus. Research Journal of Pharmacy and Technology 10(8): 2765-2770. doi:10.5958/0974-360X.2017.00490.5.

Ray, A., Gulati, K. \& Anand, R. 2016. Stress, adaptogens and their evaluation: An overview. Journal of Pharmacological Reports 1(2): 1-10.

Shahidi, F. \& Ambigaipalan, P. 2015. Phenolics and polyphenolics in foods, beverages and spices: Antioxidant activity and health effects-A review. Journal of Functional Foods 18(7): 820-897. doi:10.1016/j.jff.2015.06.018.

Singleton, V.L., Orthofer, R. \& Lamuela-Raventós, R.M. 1998. Analysis of total phenols and other oxidation substrates and antioxidants by means of folin-ciocalteu reagent. Methods in Enzymology 299: 152-178. doi:10.1016/ S0076-6879(99)99017-1.

Taguchi, C., Fukushima, Y., Kishimoto, Y., Suzuki-Sugihara, N., Saita, E., Takahashi, Y. \& Kondo, K. 2015. Estimated 
dietary polyphenol intake and major food and beverage sources among elderly Japanese. Nutrients 7(12): 1026910281. doi:10.3390/nu7125530.

Tsai, W.H., Yang, C.C., Li, P.C., Chen, W.C. \& Chien, C.T. 2013. Therapeutic potential of traditional Chinese medicine on inflammatory diseases. Journal of Traditional and Complementary Medicine 3(3): 142-151. doi:10.4103/2225-4110.114898.

Widowati, W., Herlina, T., Ratnawati, H., Constantia, G., Deva, I.D.G.S. \& Maesaroh, M. 2015. Antioxidant potential of black, green and oolong tea methanol extracts. Biology Medicine \& Natural Product Chemistry 4(2): 2089-6514.

Zaharudin, N., Staerk, D. \& Dragsted, L.O. 2019. Inhibition of $\alpha$-glucosidase activity by selected edible seaweeds and fucoxanthin. Food Chemistry 270(2018): 481-486. doi:10.1016/j.foodchem.2018.07.142.

Mohd Nazri Zayapor*

Center of Promotion and Business Development

MARDI Johor Baharu, Lot 6313

Jalan Taruka off Jalan Datin Halimah

81200 Johor Baharu, Johor Darul Takzim

Malaysia
Aminah Abdullah

Natural Medicine Research Centre

Level 7, Blok I

Bangunan MKN Embassy Techzone, Jalan Teknokrat 2 63000 Cyberjaya, Selangor Darul Ehsan

Malaysia

Mohd Nazri Zayapor* \& Wan Aida Wan Mustapha

Center for Biotechnology and Functional Food

Faculty of Science and Technology

Universiti Kebangsaan Malaysia

43600 UKM Bangi, Selangor Darul Ehsan

Malaysia

*Corresponding author; email: wanaidawm@ukm.edu.my

Received: 24 April 2019

Accepted: 17 October 2019 